\title{
Method development for arsenic analysis by modification in spectrophotometric technique
}

\author{
M. A. Tahir ${ }^{1}$, H. Rasheed ${ }^{1}$, and A. Malana ${ }^{2}$ \\ ${ }^{1}$ National Water Quality Laboratory, Pakistan Council of Research in Water Resources, Kheyaban-e-Johar, \\ H-8/1, Islamabad, Pakistan \\ ${ }^{2}$ Department of Chemistry, Bahawuddin Zikriya University, Multan, Pakistan \\ Correspondence to: M. A. Tahir (matahir2k@ hotmail.com)
}

Received: 21 July 2008 - Published in Drink. Water Eng. Sci. Discuss.: 22 August 2008

Revised: 7 July 2011 - Accepted: 24 August 2011 - Published: 4 January 2012

\begin{abstract}
Arsenic is a non-metallic constituent, present naturally in groundwater due to some minerals and rocks. Arsenic is not geologically uncommon and occurs in natural water as arsenate and arsenite. Additionally, arsenic may occur from industrial discharges or insecticide application. World Health Organization (WHO) and Pakistan Standard Quality Control Authority have recommended a permissible limit of $10 \mathrm{ppb}$ for arsenic in drinking water. Arsenic at lower concentrations can be determined in water by using high tech instruments like the Atomic Absorption Spectrometer (hydride generation). Because arsenic concentration at low limits of $1 \mathrm{ppb}$ can not be determined easily with simple spectrophotometric technique, the spectrophotometric technique using silver diethyldithiocarbamate was modified to achieve better results, up to the extent of $1 \mathrm{ppb}$ arsenic concentration.
\end{abstract}

\section{Introduction}

Arsenic is steel grey, very brittle, crystalline in nature and oxidizes on rapid heating to arsenous oxide with an odor of garlic. Arsenic exists as inorganic and organic compounds. In the environment, it combines with oxygen, chlorine and sulfur to form inorganic arsenic compounds. Arsenic also combines with carbon and hydrogen to form organo-arsenic compounds in animals and plants. Inorganic arsenic compounds are mainly used to preserve wood, and organic arsenic compounds are used as pesticides - primarily for cotton crop (Carapella, 1973; Calvert, 1975). Therefore, arsenic can be released into the environment from sources such as pesticides applications, wood preservatives, mining activities and petroleum refining. It is found exclusively as arsenite (Arsenic-III) or arsenate (Arsenic-V) in groundwater. Arsenite can be converted to arsenate under oxidizing conditions (e.g. well-aerated surface water). Likewise, arsenate can become arsenite under reducing conditions (e.g. anaerobic groundwater).

The groundwater pollution caused by arsenic in various countries of the world has led to major environmental is- sues. A number of networks supplying water in the United States, particularly in the Midwest and West regions, contain arsenic. In West Bengal of India, arsenic found in groundwater at several places is a hundred times above the permissible limits set for drinking water. The situation in Bangladesh is even worse than West Bengal. In many areas, arsenic contamination is found above $3000 \mu^{-1}$ compared to the recommended level of $10 \mu \mathrm{g}^{-1}$ (Guha Mazumder et al., 1988). Similarly, arsenic contamination is observed in Argentina, Canada, Chile, China, Greece, Japan, Mexico, Mongolia, New Zealand, South Africa, Philippines, Taiwan, Thailand and countries of the former USSR. Therefore, the arsenic poisoning is emerging as a global issue.

Arsenic monitoring is utmost important nowadays. Palmer (2001) reported atomic spectroscopy is the most widely-used method for the arsenic determination. Atomic spectroscopy involves use of the absorption characteristic of metals (Andreae, 1977; Christian and Feldman, 1970; Chu et al., 1972; Clement et al., 1973; Fishman and Spencer, 1977). USEPA (1999) reported that GFAAS (graphite furnace atomic absorption spectrometry) is an approved method by USEPA for measuring arsenic in drinking water. The 


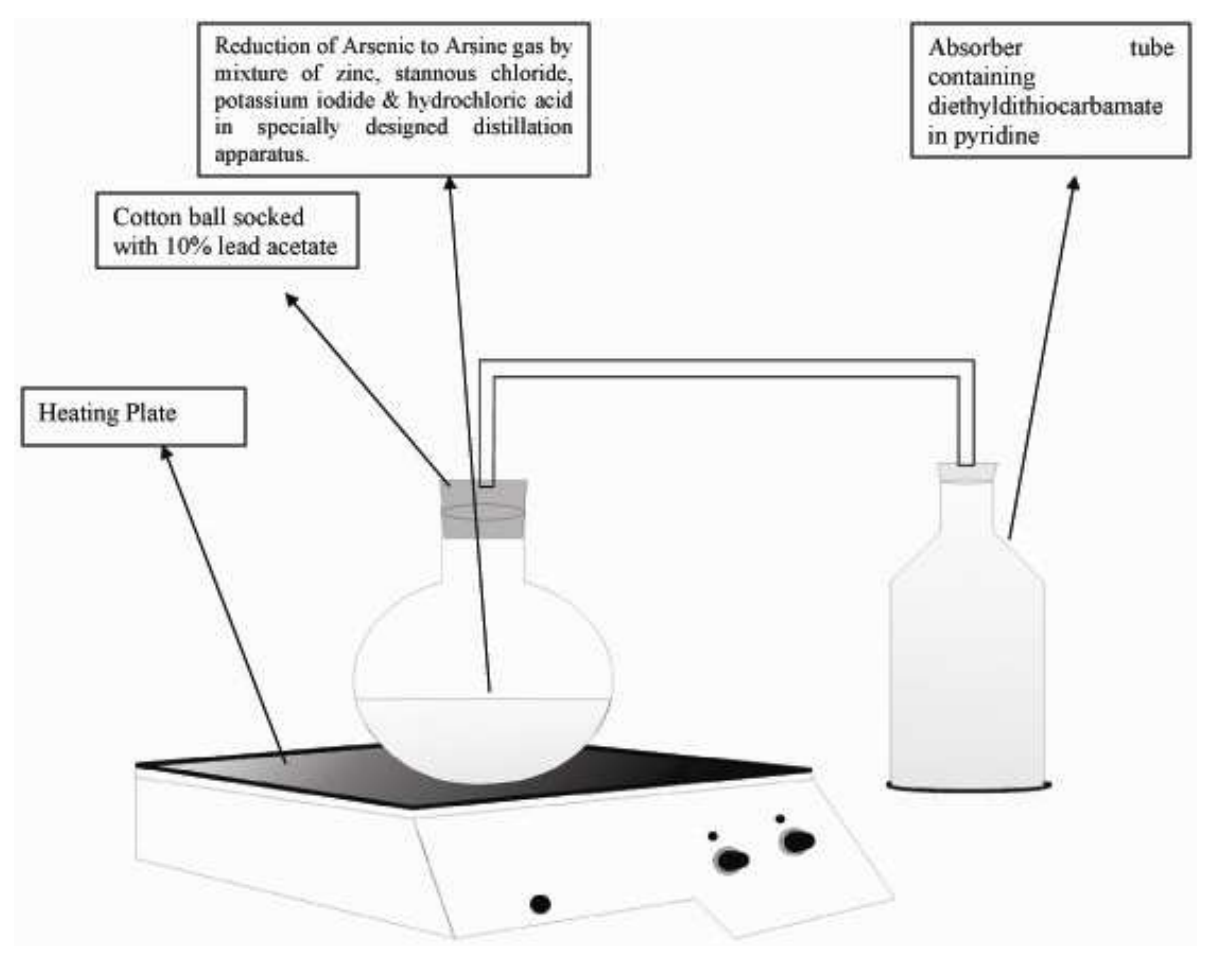

Figure 1. Arsine generation system.

detection limit for this method is $1-5 \mathrm{ppb}$. USEPA (2003) reported on the use of an ICP-AES (inductively coupled plasma atomic emission spectroscopy) instrument for the same purpose. It utilizes optical spectrometry to measure the characteristic atomic emission spectra of the analyte.

For arsenic analysis, detection limits are required to be very low $(\leq 1 \mathrm{ppb})$. It can be achieved only by state-of-theart, latest versions of equipment like the atomic absorption spectrometer or ICP. Such high-tech equipment facilities and the trained technical manpower to operate this equipment are lacking in most laboratories in the country. Spectrometers are available in most water quality laboratories; however, arsenic analysis in drinking water is quite difficult with such equipment due to the required low detection limits for arsenic. Therefore, a more practicable method for the analysis of arsenic at low detection limits on spectrophotometer was developed, which will be useful for all simple and modest laboratories.

\section{Methodology}

Analytical methods for inorganic arsenic are reported in the reference handbook (Michael, 1982) "Evaluation of Water for Pollution Control". The reference procedure is a photometric measurement using silver diethyldithiocarbamate. Arsenic analysis with the help of atomic absorption spectrometer is reported as a secondary method. We report on how the reference method was modified to some extent to get better results owing to present research work. The principle of the modified method is based on reduction of arsenic to arsine gas by a mixture of zinc, stannous chloride, potassium iodide and hydrochloric acid in a specially-designed distillation apparatus. The arsine $\left(\mathrm{AsH}_{3}\right)$ is passed through a scrubber containing cotton saturated with lead acetate and then into an absorber tube containing silver diethyldithiocarbamate in pyridine. The arsenic reacts to form a red complex, which can be read on the spectrometer.

Apparatus for the experiment consists of mainly the arsine generator, the absorption tube and the Spectrophotometer (U1100), Hitachi, Japan. Reagents consist of: arsenic standard solution BDH, UK, Hydrochloric Acid (ASC); lead acetate solution (10\%); potassium iodide solution $(20 \%)$; pyridine silver diethyldithiocarbamate (SDDC); stannous chloride solution (40\%); and zinc (0.3-1.5 mm or 14-50 mesh).

Reagent preparation for this experiment is done in the following way:

1. $1.25 \mathrm{~g}$ of silver diethyldithiocarbamate (SDDC) was transferred into a $250 \mathrm{ml}$ volumetric flask and mixed well. The reagent was stored in an amber bottle. This reagent was used as an absorber for the arsenic.

2. Standards of $0,5,15,25,35$ and $45 \mathrm{ppb}$ or $\mu \mathrm{g}^{-1}$ arsenic were prepared from $1 \mathrm{ppm}$ standard (BDH Cat. No. 455042K, Lot No. 105016109, UK). 


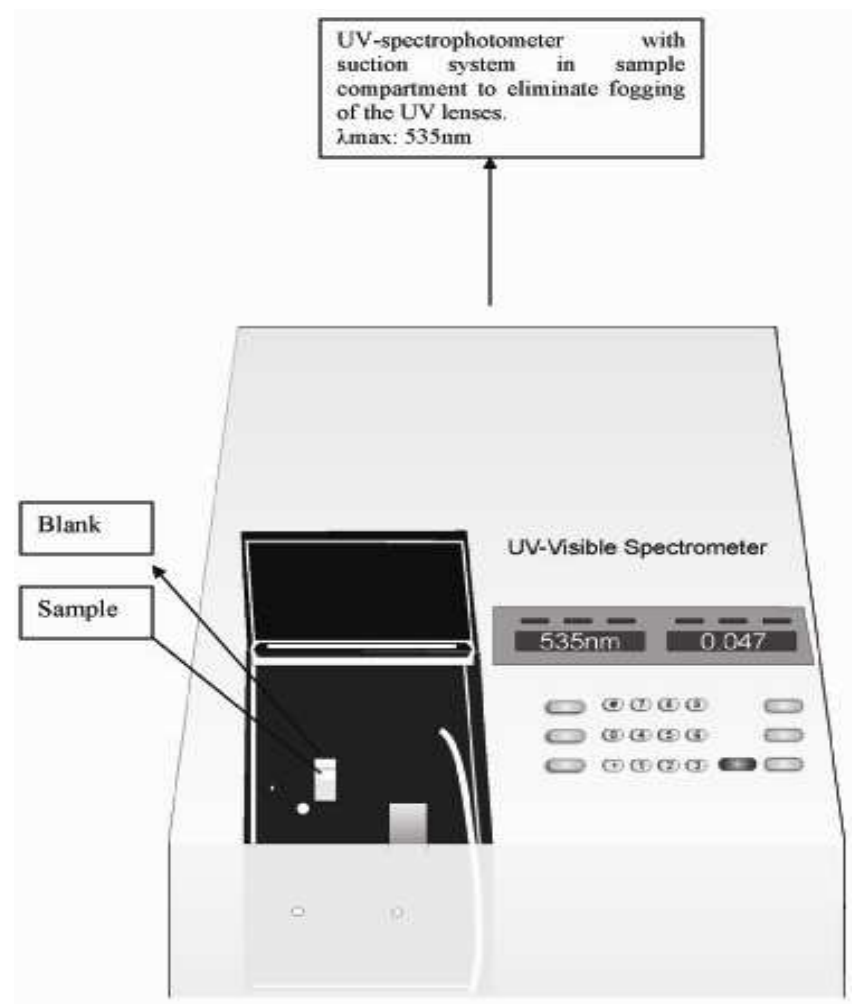

Figure 2. Suction system attached to spectrophotometer to rectify fogging problem.

\section{Procedure (modified technique)}

For evaluation of this modified technique, the standard addition technique was used to prepare arsenic-fortified solutions. For the addition of $20 \mathrm{ppb}$ arsenic in each sample, five $\mathrm{ml}$ of 1-ppm arsenic standard was transferred to a $250 \mathrm{ml}$ measuring flask; the flask was then filled to the mark with the water sample. After proper mixing, this sample was transferred into the arsenic generation or distillation apparatus (Fig. 1) under the fume hood to vent toxic fumes. A cotton ball soaked with $10 \%$ lead acetate solution was placed in the gas scrubber. Prepared arsenic absorber solution $(25 \mathrm{ml})$ was transferred into the gas bubbler assembly, which was then attached to the distillation apparatus. Then $25 \mathrm{ml} \mathrm{HCl}, 1 \mathrm{ml}$ of stannous chloride solution and $3 \mathrm{ml}$ potassium iodide solution were added to the flask, respectively. After $12 \mathrm{~min}$, $6 \mathrm{~g}$ of 14-50 mesh-sized zinc was also added to flask. The temperature was maintained at $40^{\circ} \mathrm{C}$ for $12 \mathrm{~min}$ in the beginning after adding potassium iodide solution, $60^{\circ} \mathrm{C}$ for another $12 \mathrm{~min}$ in the middle after adding zinc, and then set at $40^{\circ} \mathrm{C}$ for $16 \mathrm{~min}$ with continuous stirring at the rate of 100 to $150 \mathrm{rpm}$.

After the completion of reaction time (about $40 \mathrm{~min}$ ), a dry sample cell was filled with un-reacted arsenic absorber solution (the blank) and the other one filled with reacted arsenic absorber. Finally, arsenic concentration was deter- mined by using concentration mode on the pre-calibrated spectrophotometer at $535 \mathrm{~nm}(\lambda \max$.$) . The added concentra-$ tion, i.e. $20 \mathrm{ppb}$, was deducted from final concentration calculations of each sample. Standard addition is a widely accepted technique for checking the validity of test results. It is known as "Spiking" and "Known addition". This technique is also used to check the performance of the reagents, instrument, apparatus, procedure and also to enhance the lower detection limit.

It was observed that fumes of arsenic absorber solution present in the $10 \mathrm{~mm}$ rectangular quartz cell with lid were responsible for fogging the lenses installed in the sample compartment, which were ultimately responsible for undesired results. Another source of unwanted results, especially in such a low concentration, is the electricity supplied to the spectrometer (variation in voltage). Making amendments in the equipment, as shown in Fig. 2, rectified the problem of fogging. Amendments included suction tube at upper side of the lenses (window) followed by a suction pump and a stabilizer. The problem of voltage variation was controlled with the help of the addition of a stabilizer as shown in Fig. 3.

\section{Results and discussions}

According to procedure, arsenic was reduced to arsine gas and formed a red complex with silver diethyldithiocarbamate. For the selection of suitable wavelength, absorbances and transmittances (\%) were noted on spectrophotometer for known standard solutions, i.e. 0, 25, 35 and $45 \mathrm{ppb}$, after adopting the above procedure. Results are presented in Table 1 .

From the results, it was concluded that maximum absorbances were noted at $535 \mathrm{~nm}$ in all cases. However, absorbances were found to be almost the same from 535 to $540 \mathrm{~nm}$. The chances of interferences in this method are almost negligible except for antimony salts, which may interfere in color development. Therefore, $535 \mathrm{~nm}$ was selected as $\lambda$ max as shown in Fig. 4.

Correlation between absorbance vs. known concentrations was developed with the help of the regression model in light of experimental data shown in Table 2. Graphical views (xy) are shown in Figs. 5 and 6. First and second views reflected relationship between absorbance and concentration with or without straight line. The degree of fitness or $\mathrm{R}$ square is near to 1 , which indicated good relationship between $\mathrm{x}$ and $\mathrm{y}$. The developed co-relation, degree of fitness or $\mathrm{R}$ square and value of constant, are given below:

Concentration of As $=983.4$ X Absorbance -0.8014

Degree of fitness or $R_{2}=0.9958$

Constant $=-0.8014$

$\mathrm{X}$ Coefficient $=983.4$ 


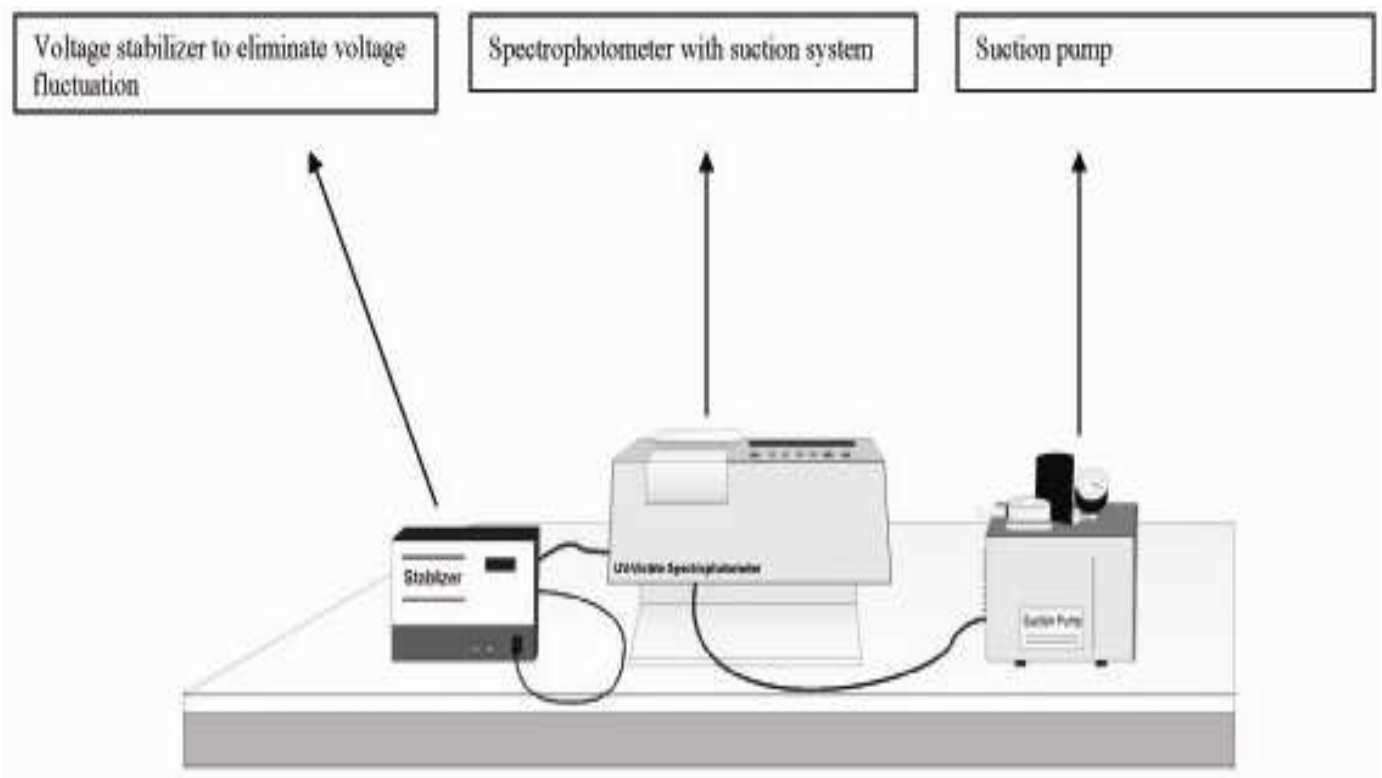

Figure 3. Suction system to rectify fogging problem and stabilizer to control voltage variation.

Table 1. Absorbance of standard solution at different $\lambda$ range.

\begin{tabular}{|c|c|c|c|c|c|c|c|c|}
\hline \multirow{2}{*}{$\begin{array}{l}\text { Standard } \\
\text { Solution } \\
(\mathrm{nm})\end{array}$} & \multicolumn{2}{|c|}{$0.000 \mathrm{ppb}$} & \multicolumn{2}{|c|}{$0.025 \mathrm{ppb}$} & \multicolumn{2}{|c|}{$0.035 \mathrm{ppb}$} & \multicolumn{2}{|c|}{$0.045 \mathrm{ppb}$} \\
\hline & Abs. & $\mathrm{T} \%$ & Abs. & $\mathrm{T} \%$ & Abs. & $\mathrm{T} \%$ & Abs. & $\mathrm{T} \%$ \\
\hline 520 & 0 & 0 & 0.015 & 96.6 & 0.026 & 94.2 & 0.037 & 91.8 \\
\hline 521 & 0 & 0 & 0.016 & 96.4 & 0.026 & 94.2 & 0.037 & 91.8 \\
\hline 522 & 0 & 0 & 0.016 & 96.4 & 0.027 & 94 & 0.038 & 91.6 \\
\hline 523 & 0 & 0 & 0.017 & 96.2 & 0.028 & 93.7 & 0.039 & 91.4 \\
\hline 524 & 0 & 0 & 0.018 & 95.9 & 0.029 & 93.5 & 0.041 & 91 \\
\hline 525 & 0 & 0 & 0.019 & 95.7 & 0.03 & 93.4 & 0.042 & 90.8 \\
\hline 526 & 0 & 0 & 0.02 & 95.5 & 0.031 & 93.2 & 0.043 & 90.6 \\
\hline 527 & 0 & 0 & 0.021 & 95.3 & 0.032 & 92.9 & 0.043 & 90.6 \\
\hline 528 & 0 & 0 & 0.022 & 95.1 & 0.033 & 92.7 & 0.044 & 90.4 \\
\hline 529 & 0 & 0 & 0.023 & 94.9 & 0.034 & 92.5 & 0.045 & 90.2 \\
\hline 530 & 0 & 0 & 0.023 & 94.9 & 0.034 & 92.5 & 0.045 & 90 \\
\hline 531 & 0 & 0 & 0.024 & 94.7 & 0.035 & 92.3 & 0.046 & 90 \\
\hline 532 & 0 & 0 & 0.025 & 94.4 & 0.035 & 92.3 & 0.046 & 90 \\
\hline 533 & 0 & 0 & 0.025 & 94.4 & 0.035 & 92.3 & 0.046 & 90 \\
\hline 534 & 0 & 0 & 0.025 & 94.4 & 0.035 & 92.3 & 0.046 & 90 \\
\hline 535 & 0 & 0 & 0.026 & 94.2 & 0.036 & 92.1 & 0.047 & 89.7 \\
\hline 536 & 0 & 0 & 0.026 & 94.2 & 0.036 & 92.1 & 0.047 & 89.7 \\
\hline 537 & 0 & 0 & 0.026 & 94.2 & 0.036 & 92.1 & 0.047 & 89.7 \\
\hline 538 & 0 & 0 & 0.026 & 94.2 & 0.036 & 92.1 & 0.047 & 89.7 \\
\hline 539 & 0 & 0 & 0.026 & 94.2 & 0.036 & 92.1 & 0.047 & 89.7 \\
\hline 540 & 0 & 0 & 0.026 & 94.2 & 0.036 & 92.1 & 0.047 & 89.7 \\
\hline
\end{tabular}




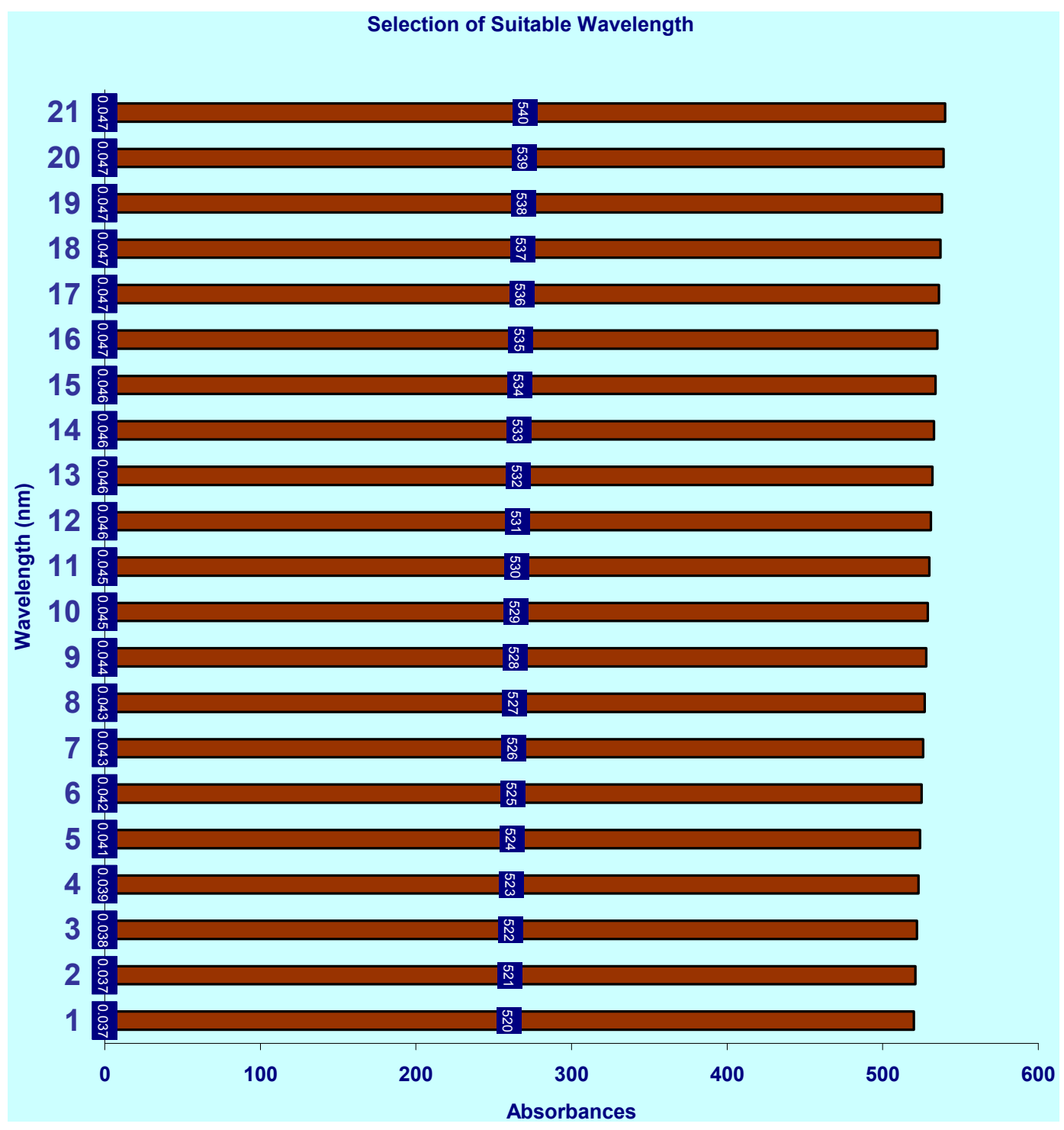

Figure 4. $0.45 \mathrm{ppb}$ arsenic standard at different wavelengths.

Table 2. Arsenic concentration vs. absorbance.

\begin{tabular}{ccc}
\hline Sr. No. & Concentration $(\mathrm{ppb})$ & Absorbance \\
\hline 1 & 0 & 0 \\
2 & 5 & 0.008 \\
3 & 15 & 0.015 \\
4 & 25 & 0.026 \\
5 & 35 & 0.036 \\
6 & 45 & 0.047 \\
\hline
\end{tabular}

ARSENIC DETERMINATION IN WATER BY SILIVER DIETHYLDITHIOCARBAMATE METHOD

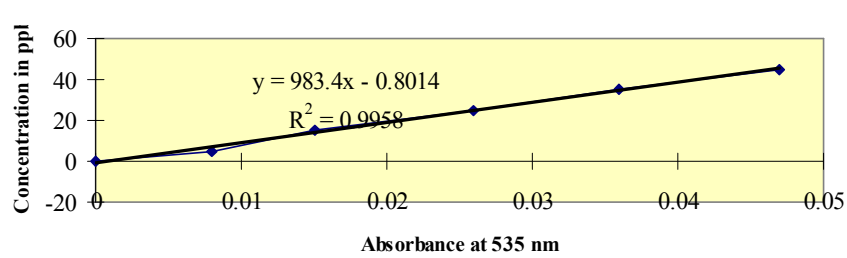

Figure 5. Absorbance vs. concentration with straight line. 


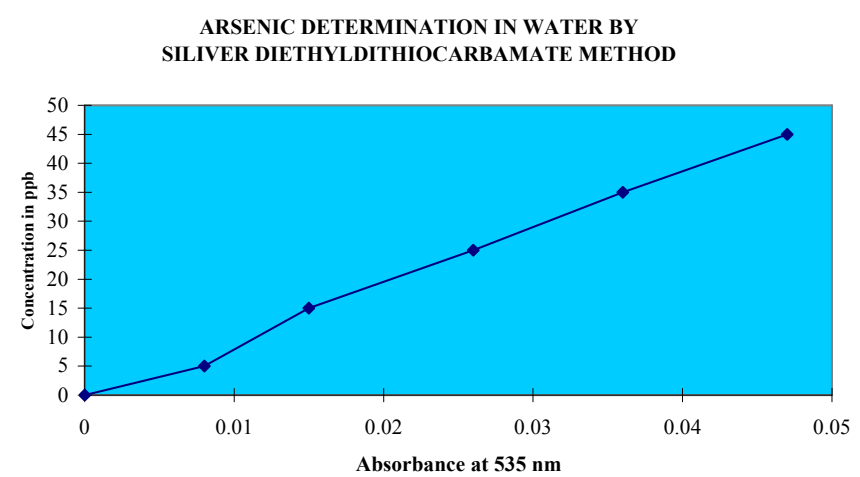

Figure 6. Absorbance vs. concentration without straight line.

Table 3. Spectrometer vs. AAS (As Analysis).

\begin{tabular}{ccc}
\hline Sr. \# & Spectrometer (ppb) & AAS (ppb) \\
\hline 1 & 2 & 2 \\
2 & 5 & 4 \\
3 & 2 & 1 \\
4 & 5 & 4 \\
5 & 2 & 1 \\
6 & 0 & 0 \\
7 & 2 & 1 \\
8 & 5 & 3 \\
9 & 16 & 15 \\
10 & 3 & 4 \\
11 & 2 & 1 \\
12 & 0 & 1 \\
13 & 5 & 4 \\
14 & 2 & 2 \\
15 & 3 & 2 \\
\hline
\end{tabular}

Fifteen water samples were analyzed by pre-calibrated spectrophotometer at $535 \mathrm{~nm}$ ( $\lambda$ max.) using the modified method on concentration mode. The same numbers of samples were analyzed by atomic absorption spectrometer. The results can be seen in Table 3 and graphical view is shown in Fig. 7. The difference in concentration is \pm 1 to $2 \mathrm{ppb}$, which is not noteworthy at very lower concentrations. The comparison of this modified technique with other commonly used spectrometric techniques, i.e. APHA Method, HACH and WHO, is given in Table 4.

\section{Conclusions}

The combination of high toxicity and widespread occurrence of arsenic has created a pressing need for effective monitoring and measurement of arsenic in soil and groundwater. Technological advances in a variety of analytical instruments

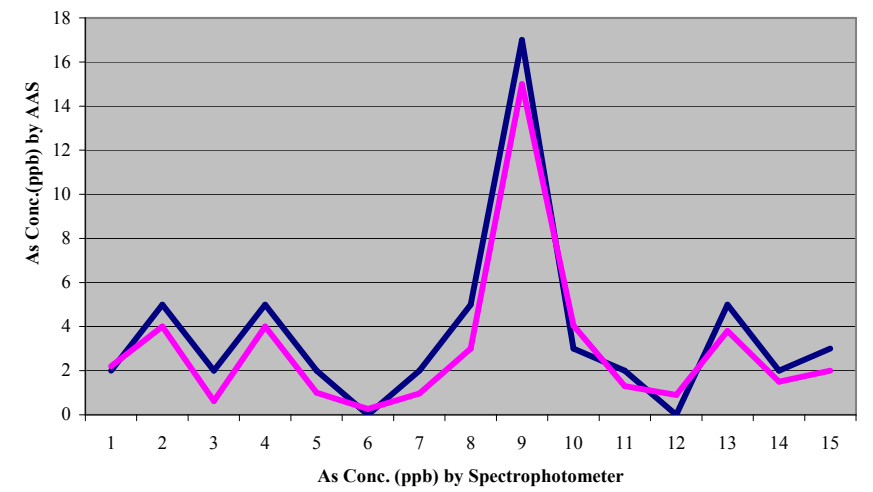

Figure 7. Comparison of arsenic analysis.

have made improvements in accuracy and detection limit. However, the development of a cost-effective and reliable technique for arsenic determination by using a comparatively inexpensive instrument like spectrometer is what is needed at this time, especially in developing countries facing an arsenic contamination problem. Most laboratories in these countries lack state-of-the-art equipment like the Atomic Absorption Spectrometer (AAS) or the Inductive Coupled Plasma Spectrometer (ICP) to analyze arsenic at low detection levels. This paper presents a brief overview of the scientific literature on existing technologies used for arsenic analysis in the groundwater and also includes research developments in this area. The World Health Organization (WHO) has recommended a guideline value of $10 \mathrm{ppb}$ for arsenic, which is analyzed in most of laboratories on high tech equipment like AAS and ICP due to low this detection limit. These instruments need trained technical manpower to operate and maintain. Many laboratories are unable to analyze arsenic due to lack of such equipment and manpower. Spectrophotometer is a commonly available instrument in most of laboratories. Considering this fact, the modified spectrophotometric method presented here has been developed for the analysis of arsenic at low detection limit. The comparative analytical evaluation on spectrophotometer with modified technique vs. Atomic Absorption Spectrometer reveals almost similar results ( \pm 1 to $2 \mathrm{ppb}$ ). Hopefully this modified method will be useful to enhance the analytical capabilities with respect to arsenic determination in most laboratories.

Acknowledgement. The authors are grateful to Mr. Ignaz Worm for his help editing of this manuscript.

Edited by: I. Worm 
Table 4. Comparison of modified technique with other spectrometric methods.

\begin{tabular}{|c|c|c|c|c|}
\hline Steps & $\begin{array}{l}\text { Modified Analytical } \\
\text { Technique (2002) }\end{array}$ & HACH Method (1997) & $\begin{array}{l}\text { Standard Methods } \\
\text { (APHA, 1992) }\end{array}$ & $\begin{array}{l}\text { Reference Method by } \\
\text { WHO (Michael, 1982) } \\
\text { and Standard Methods } \\
\text { (APHA, 1971) }\end{array}$ \\
\hline I & $\begin{array}{l}\text { Dampen a cotton ball in } \\
10 \% \text { lead acetate solu- } \\
\text { tion and put it at appro- } \\
\text { priate place. }\end{array}$ & Same & Same & Same \\
\hline II & $\begin{array}{l}25 \mathrm{ml} \text { of prepared ar- } \\
\text { senic absorber solution } \\
\text { into absorber tube. }\end{array}$ & $\begin{array}{l}25 \mathrm{ml} \text { prepared arsenic ab- } \\
\text { sorber solution into absorber } \\
\text { tube. }\end{array}$ & $\begin{array}{l}4 \mathrm{ml} \text { of SDDC into absorber } \\
\text { tube. }\end{array}$ & Same \\
\hline III & $\begin{array}{l}5 \mathrm{ml} \text { of } 1-\mathrm{ppm} \text { arsenic } \\
\text { standard added into } \\
250 \mathrm{ml} \text { flask and volume } \\
\text { make up with sample. }\end{array}$ & No standard addition & No standard addition & No standard addition \\
\hline IV & $\begin{array}{l}\text { Volume of sample } \\
\simeq 245 \mathrm{ml}\end{array}$ & $250 \mathrm{ml}$ sample taken. & $70 \mathrm{ml}$ sample taken. & $35 \mathrm{ml}$ sample taken. \\
\hline $\mathrm{V}$ & $\begin{array}{l}\text { Stirring (100-150 rpm) } \\
\text { continued up to step-XII. }\end{array}$ & $\begin{array}{l}\text { Stir control set to } 5 \text { and heat } \\
\text { control to } 0 .\end{array}$ & $\begin{array}{l}\text { Stirring continued up to } \\
\text { Step-XI. }\end{array}$ & No stirring. \\
\hline VI & $\begin{array}{l}\text { Added } 25 \mathrm{ml} \text { conc. } \mathrm{HCl} \\
\text { into generation flask of } \\
250 \mathrm{ml} \text { volume }\end{array}$ & $\begin{array}{l}\text { Added } 10 \mathrm{ml} \text { acetate buffer } \\
\text { and flushed with Nitrogen } \\
\text { gas at } 60 \mathrm{ml} \mathrm{min}{ }^{-1}\end{array}$ & 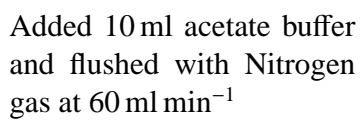 & $\begin{array}{l}\text { Added } 5 \mathrm{ml} \text { conc. HCL } \\
\text { into generation flask. }\end{array}$ \\
\hline VII & $\begin{array}{l}\text { Added } 1 \mathrm{ml} \text { of stannous } \\
\text { chloride. }\end{array}$ & $\begin{array}{l}15 \mathrm{ml} \text { of } 1 \% \text { sodium borohy- } \\
\text { dride injected within } 2 \text { min. }\end{array}$ & $\begin{array}{l}15 \mathrm{ml} \text { of } 1 \% \text { sodium boro- } \\
\text { hydride injected within } \\
2 \mathrm{~min} .\end{array}$ & $\begin{array}{l}\text { Added } 0.40 \mathrm{ml} \text { of stan- } \\
\text { nous chloride. }\end{array}$ \\
\hline VIII & $\begin{array}{l}\text { Added } 3 \mathrm{ml} \text { of potassium } \\
\text { iodide solution. }\end{array}$ & $\begin{array}{l}\text { Additional } \mathrm{N}_{2} \text { gas flushing } \\
\text { for } 15 \mathrm{~min} \text {. }\end{array}$ & $\begin{array}{l}\text { Additional } \mathrm{N}_{2} \text { gas flushing } \\
\text { for } 15 \mathrm{~min} \text {. }\end{array}$ & $\begin{array}{l}\text { Added } 2 \mathrm{ml} . \text { Of potas- } \\
\text { sium iodide solution. }\end{array}$ \\
\hline IX & $\begin{array}{l}12 \text { min given as "Reac- } \\
\text { tion Time" at } 40^{\circ} \mathrm{C} \text {. }\end{array}$ & $\begin{array}{l}15 \mathrm{~min} \text { given as reaction } \\
\text { time. }\end{array}$ & - & $\begin{array}{l}15 \text { min given as reaction } \\
\text { time without heat control }\end{array}$ \\
\hline $\mathrm{X}$ & $\begin{array}{l}6 \mathrm{~g} \text { zinc added }(0.3- \\
1.5 \mathrm{~mm} \text { or } 14-50 \text { mesh } \\
\text { size })\end{array}$ & $6 \mathrm{~g}$ zinc added (20 mesh size) & - & Added $3 \mathrm{~g}$ of zinc. \\
\hline $\mathrm{XI}$ & $\begin{array}{l}12 \text { min given as reaction } \\
\text { time at } 60^{\circ} \mathrm{C} \text {. }\end{array}$ & $\begin{array}{l}15 \text { min given as reaction time } \\
\text { and heat control set at } 3 \text {. }\end{array}$ & - & $\begin{array}{l}30 \text { min given as reaction } \\
\text { time without heat con- } \\
\text { trol. }\end{array}$ \\
\hline XII & $\begin{array}{l}16 \text { min given as reaction } \\
\text { time at } 40^{\circ} \mathrm{C} \text {. }\end{array}$ & $\begin{array}{l}15 \text { min given as reaction time } \\
\text { and heat control set at } 1 .\end{array}$ & - & - \\
\hline XIII & $\begin{array}{l}\text { Measurement of blank } \\
\text { and sample on spec- } \\
\text { trophotometer at } 535 \mathrm{~nm} \text {. }\end{array}$ & $\begin{array}{l}\text { Measurement of blank and } \\
\text { sample on spectrophotometer } \\
\text { at } 520 \mathrm{~nm} \text {. }\end{array}$ & $\begin{array}{l}\text { Measurement of blank and } \\
\text { sample on spectrophotome- } \\
\text { ter at } 520 \mathrm{~nm} \text {. }\end{array}$ & $\begin{array}{l}\text { Measurement of blank } \\
\text { and sample on spec- } \\
\text { trophotometer at } 535 \mathrm{~nm} \text {. }\end{array}$ \\
\hline
\end{tabular}




\section{References}

Andreae, M. O.: Determination of arsenic species in natural waters, Anal. Chem., 49, 820-825, 1977.

APHA, AWWA and WEF: Standard Methods for the Examination of Water and Wastewater, 13th Edn., American Public Health Association, American Water Works Association and Water Environment Federation, Washington, DC, 62-66, 1971.

APHA, AWWA and WEF: Standard Methods for the Examination of Water and Wastewater, 18th Edn., American Public Health Association, American Water Works Association and Water Environment Federation, Washington, DC, 3-50, 1992.

Calvert, C. C.: Arsenicals in animal feeds and wastes, in: Arsenical Pesticides, edited by: Woolson, E. A., Washington, DC, American Chemical Society (ACS Symp. Series No. 7), 1975.

Carapella, S. C.: Arsenic and compounds, in: The encyclopedia of chemistry, third edn., edited by: Hampel, C. A. and Hawley, G. G., New York, Van Nostrand Reinhold Company, 1973.

Christian, G. D. and Feldman, F. J.: Atomic absorption spectroscopy; Applications in agriculture, biology, and medicine, New York, Wiley-Interscience, 188-195, 1970.

Chu, R. C., Barron, G. P., and Baumgarner, P. A.: Arsenic determination at sub-microgram levels by arsine evolution and flameless atomic absorption spectrophotometric technique, Anal. Chem., 44, 1476-1479, 1972.
Clement, W. H. and Faust, S. D.: A new convenient method for determining arsenic (+3) in natural waters, Environ. Lett., 5, 155164, 1973.

Fishman, M. and Spencer, R.: Automated atomic absorption spectrometric determination of total arsenic in water and streambed materials, Anal. Chem., 49, 1599-1602, 1977.

Guha Mazumder, D. N., Chakraborty, A. K., and Ghose, A.: Chronic arsenic toxicity from drinking tubewell water in rural West Bengal, B. World Health Organ., 66, 499-506, 1988.

Michael, J. S.: Examination of water for pollution control, Vol. 2. First Edn., World Health Organization; 179-186, 1982.

Palmer, P. T.: A Review of Analytical Methods for the Determination of Mercury, Arsenic and Pesticides Residues on Museum Object, Department of Chemistry and Biochemistry, San Francisco State University, San Francisco, California, Collection Forum, 16, 25-41, 2001.

USEPA: Arsenic in Drinking Water: Analytical Methods, US Environmental Protection Agency, United States Environmental Protection Agency, Washington, DC, 1999.

USEPA: List of Drinking Water Contaminants \& MCLS.EPA 816F03-D, United States Environmental Protection Agency, Washington, DC, 2003. 